\section{(1) \\ CrossMark}

\title{
Bacterial lysate therapy for the prevention of wheezing episodes and asthma exacerbations: a systematic review and meta-analysis
}

\author{
Geertje Maria de Boer (10 ${ }^{1,2}$, Jakub Żółkiewicz $\mathbb{1}^{3,7}$, Konrad Piotr Strzelec ${ }^{3}$, \\ Marek Ruszczyński $\mathbb{1}^{4}$, Rudi W. Hendriks ${ }^{2}$, Gert-Jan Braunstahl (i) ${ }^{1,2}$, \\ Wojciech Feleszko $\mathbb{1}^{3}$ and Gerdien. A. Tramper-Stranders (10) 5
}

Affiliations: ${ }^{1}$ Dept of Pulmonary Medicine, Franciscus Gasthuis \& Vlietland, Rotterdam, The Netherlands. ${ }^{2}$ Dept of Pulmonary Medicine, Erasmus MC, Rotterdam, The Netherlands. ${ }^{3}$ Dept of Paediatric Allergy and Pulmonology, The Medical University of Warsaw, Warsaw, Poland. ${ }^{4}$ Dept of Paediatrics, The Medical University of Warsaw, Warsaw, Poland. ${ }^{5}$ Dept of Paediatric Medicine, Franciscus Gasthuis \& Vlietland, Rotterdam, The Netherlands. ${ }^{6}$ Dept of Neonatology, Erasmus MC-Sophia, Rotterdam, The Netherlands. ${ }^{7}$ Joint first authors.

Correspondence: Wojciech Feleszko, Dept of Paediatric Allergy and Pulmonology, Medical University of Warsaw, Medical University Children's Hospital, Warsaw, 01-612, Poland. E-mail: wojciech.feleszkođawum. edu.pl

@ERSpublications

Bacterial lysates reduce the number of respiratory tract infections by immune modulation; we show evidence for prevention of wheezing episodes and asthma exacerbations by bacterial lysates. Thus, they might be a promising add-on therapy in asthma. https://bit.ly/3dunDLG

Cite this article as: de Boer GM, Żółkiewicz J, Strzelec KP, et al. Bacterial lysate therapy for the prevention of wheezing episodes and asthma exacerbations: a systematic review and meta-analysis. Eur Respir Rev 2020; 29: 190175 [https://doi.org/10.1183/16000617.0175-2019].

ABSTRACT Wheezing and asthma are a growing cause of morbidity in children and adults. Treatment is aimed at prevention of disease exacerbations and preservation of lung function. Respiratory viruses are involved in $\sim 40-60 \%$ of exacerbations. Bacterial lysates prevent recurrent respiratory tract infections and might reduce exacerbations. Moreover, immunomodulatory effects have been observed in human and animal studies.

Here we aimed to assess the effects of bacterial lysate therapy on preschool wheezing episodes and asthma exacerbation frequency. We performed a systematic literature review based on the Preferred Reporting Items for Systematic reviews and Meta-Analysis (PRISMA) statement and a meta-analysis using Cochrane Review Manager. Out of 2016 retrieved articles, 22 studies were included, of which five provided sufficient data for a meta-analysis.

The use of bacterial lysates showed a decrease of both wheezing episodes (mean difference -2.35 $(-3.03--1.67), \mathrm{p}<0.001)$ and asthma exacerbations in children (mean difference $-0.90(-1.23--0.57)$, $\mathrm{p}<0.001)$. Additionally, antibiotic use was reduced, and the duration of wheezing episodes was also decreased. No data for adults with asthma are currently available. The immunomodulatory effect seems to be dependent on increased T-helper (Th)1-cell activation and Th2-cell suppression.

These favourable effects of bacterial lysates indicate that they show promise as add-on therapy in preschool wheezing and childhood asthma.

\section{Provenance: Submitted article, peer reviewed}

This article has supplementary material available from err.ersjournals.com

Received: 18 Dec 2019 | Accepted after revision: 26 May 2020

Copyright $\odot$ ERS 2020. This article is open access and distributed under the terms of the Creative Commons Attribution Non-Commercial Licence 4.0. 


\section{Introduction}

Nearly $9 \%$ of children and adults in Europe suffer from asthma [1]. More importantly, asthma and especially acute asthma exacerbations are a growing cause of morbidity for children and adults [2, 3]. The early stages of asthma include preschool wheezing, which affects up to $10-30 \%$ of children. Nearly $15-25 \%$ of children experience recurrent wheezing before school age [4].

Wheezing lower respiratory illnesses in infants and toddlers are usually initially triggered by viral respiratory tract infections (RTIs) and are associated with a high level of inflammation and airway remodelling [5]. Recurrent wheezing may significantly increase the risk of developing permanent wheeze or asthma later in life, with irreversible effects on lung function. The risk may be further amplified when associated with early sensitisation to aeroallergens [6]. Current treatment options for preschool wheezing seem unsatisfactory. Recently an international survey has revealed an overall frustration with existing diagnostics and insufficient treatment options [7].

Asthma exacerbations are defined as an acute or subacute worsening of symptoms from the patient's usual status and are treated with oral corticosteroids and in some cases antibiotics. Exacerbations are mainly induced by allergic stimuli and RTIs, the latter accounting for $\sim 40-60$ of exacerbations [8]. Exacerbation prevention is mostly realised by improved therapy compliance and lifestyle interventions [9-11]. Nevertheless, in patients with severe eosinophilic and allergic asthma, monoclonal antibodies targeting the immunoglobulin (Ig)E, interleukin (IL)-4 and IL-5 inflammatory pathways are an important treatment strategy in exacerbation prevention. Other than hygiene measures and a healthy lifestyle, no specific antiviral therapy is broadly available to prevent viral RTIs [12-15]. In this context of unmet needs, boosting the host immune response against viral infections by immunomodulators may offer a novel preventive approach.

Considering that the majority of wheezing respiratory illnesses, as well as asthma exacerbations, begin in the upper airways, it is likely that an effective strategy to reduce the risk for asthma exacerbations may be the prevention of upper RTIs, including colds. Several studies suggest vaccinations or nonspecific immunomodulators are effective in this area [16].

Since the early 1950s, orally delivered nonspecific bacterial-derived preparations (bacterial lysates or immunomodulators) have been used in Europe and Asia for the prevention of recurrent RTIs [8, 12, 13]. Bacterial lysates consist of inactivated bacterial extracts from pathogenic respiratory bacteria [5] and are relatively safe without reports of associated serious adverse events. Bacterial antigens used in these lysates are mainly obtained by either chemical (polyvalent chemical bacterial lysate (PCBL)) or mechanical (polyvalent mechanical bacterial lysate (PMBL)) cellular lysis of cultures of bacterial strains followed by lyophilisation $[13,15,17,18]$.

The ability of bacterial lysates to prevent RTIs has been shown in several animal studies. Mouse studies show a protective effect against influenza and bacterial superinfection after bacterial lysate administration [19]. In humans, a $\sim 30-40 \%$ reduction in RTIs with bacterial lysates has been estimated in two meta-analyses $[16,20]$. Their immunomodulatory activity is mainly based on dendritic cell activation through the nuclear factor- $\mathrm{KB}$ and mitogen-activated protein kinase pathways [21]. This activation results in the stimulation of the antiviral response by its effect on the production of antiviral cytokines, including interferons (IFNs), classical T-helper (Th) 1 cytokines and (local) Igs [18, 19, 22, 23]. These changes in Igs are accompanied by an increased secretion of B-cell activating factor [21]. Nevertheless, the exact working mechanism, as well as potential biomarkers, has not been completely unravelled yet.

Although most published studies with bacterial lysates in wheezing and asthma seem promising, they vary in patient characteristics, numbers and methods applied. Therefore, we aimed to systematically assess the clinical and immunological effects of bacterial lysates as an add-on therapy for the prevention of wheezing episodes and asthma exacerbations in children, adolescents and adults.

\section{Methods}

This review and meta-analysis follows the Preferred Reporting Items for Systematic reviews and Meta-Analysis (PRISMA) statements [24] throughout and was registered in PROSPERO (www.crd.york.ac. uk/prospero CRD42017078141) [25]. The meta-analysis was performed using Revman 5.3 [26].

Embase, Medline, Cochrane and Web of Science were searched from inception to the end of September 2019. Studies lacking an available English, German or French abstract were excluded from this search. The search terms can be found in the supplementary figure.

Search results were extended by an extensive hand search and recently presented abstracts were screened on eligibility. Article selection for further analysis was based on the following inclusion criteria: 1) humans with asthma and/or preschool wheezing; 2) animal/laboratory studies with asthma models; and 3) bacterial 
lysates as an intervention. Management guidance documents, study protocols and studies on COPD were excluded. All data were independently extracted by pairs of investigators (G.M. de Boer, J. Żółkiewicz and M. Ruszczyński) and underwent a triple cross-reference procedure by using a standardised protocol and data extraction form. Subsequently, the risk of bias in all included studies was assessed by using the Cochrane Risk of Bias Tool. Disagreements were resolved with a consultation of three other researchers (G.J. Braunstahl, G.A. Tramper-Stranders and W. Feleszko).

Data were extracted from all selected articles, regardless of whether the results were positive or negative, to present a fair and unbiased account of the available published evidence.

According to the Cochrane Handbook, all data were quantified using mean differences and standardised mean differences with $95 \%$ confidence intervals and were pooled using a random-effects model, since heterogeneity between the studies was high.

Statistical heterogeneity was addressed using the $\mathrm{I}^{2}$ statistics $(\mathrm{p}<0.05$ considered significant), as well as through visual inspection of L'Abbé plots and defined as low, moderate or high $\left(\mathrm{I}^{2} \leqslant 25 \%, 26-\leqslant 50 \%\right.$ and $>50 \%$, respectively) [27].

Sensitivity analyses were performed by careful consideration and omitting one study per analysis to identify the potential cause. In order to examine a potential source of heterogeneity, we collaterally performed pre-planned analysis based on using bacterial lysates: PMBL versus PCBL.

\section{Outcome measures}

The primary outcome measurement was the difference in wheezing episodes and asthma exacerbation frequency after the use of bacterial lysates. Secondary outcome measurements were: 1) time to first wheezing episode/asthma exacerbation; 2) asthma control; 3) duration of wheezing episodes/asthma exacerbation in days; 4) duration of antibiotic treatment in days; 5) hospital admission days; and 6) immunological effects of bacterial lysates.

\section{Specifications of bacterial lysates used in included studies}

Bacterial lysates used in clinical studies are generally PMBL and PCBL. All bacterial lysates, except for MV130, contain lysates of the following pathogens: 1) Haemophilus influenzae; 2) Streptococcus pneumoniae, S. pyogenes and viridans streptococci; 3) Klebsiella pneumoniae and K. ozaenae; 4) Staphylococcus aureus; and 5) Moraxella catarrhalis [28, 29]. MV310 lacks some Streptococcus and Klebsiella subtypes.

$P C B L$

OM-85 was the only PCBL used in the included studies. It is known under several trade names including Broncho-Vaxom, OM-85BV, Broncho Munal, Ommunal, Imoccur, Vaxoral and Paxoral. The bacteria are cultured in batches, inactivated by heat and subjected to alkaline lysis after being harvested. The lysates of these 21 bacteria are mixed and lyophilised. OM-85 is taken orally with some fluid. The drug is available in two dosage forms: $7.0 \mathrm{mg}$ capsules for adults and $3.5 \mathrm{mg}$ capsules or sachets for children [28].

PMBL

Ismigen and MV130 were the PMBLs used in the included studies. Ismigen is also known as Immubron, Bromunyl, Respibron and Bactovax. The tablets are taken sublingually on an empty stomach. The drug is available as a $10.0 \mathrm{mg}$ sublingual tablet for adults and children [29]. MV130 is known under the trade name Bactek. It is a suspension, which is sprayed sublingually daily [14].

\section{Results}

Search

In the initial search, 2016 records were identified in electronic databases (figure 1). Four additional studies were identified from recently presented abstracts at various meetings. After screening, 46 articles were reviewed in detail. Finally, 22 original studies, of which five clinical studies in preschool wheezing, five clinical studies in asthma and 12 laboratory studies were included in this review. One study included patients with COPD, asthma and allergic rhinitis, in which a patient-control model was used. In this review, we analysed only the asthma patients of this study [30].

\section{Study characteristics}

Out of 10 clinical studies included in this systematic review, five studies were excluded from the meta-analysis due to the following reasons: 1) lack of numerical data [31]; 2) no precise defined end-points [32]; 3) lack of means and numerical data [33]; 4) data were not sufficient for analysis [34]; and 5) no subgroup analysis for asthma was performed [30]. A total of 778 unique patients were included 


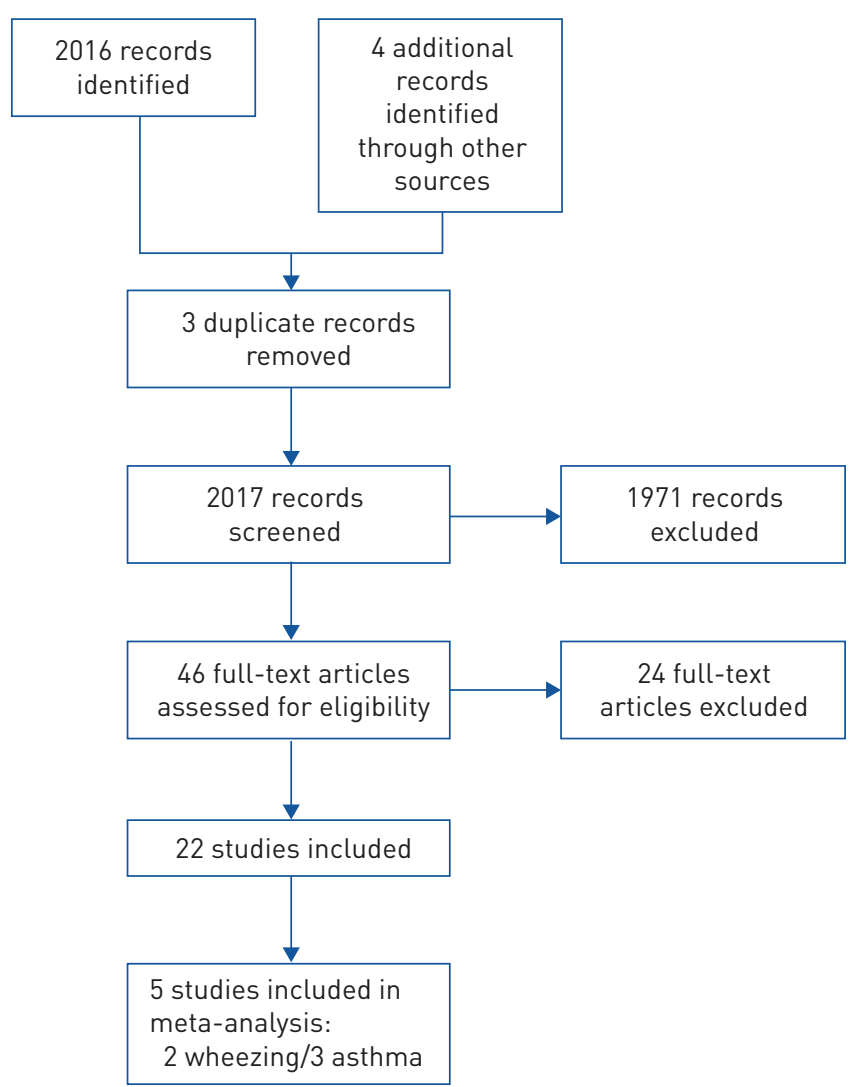

in this systematic review and 450 were included in the meta-analysis (table 1) $[29,30,32,35,36]$. The age range at inclusion was between 3 months and 65 years. All studies compared bacterial lysates to standard care or placebo. Study follow-up lasted between 3 and 12 months. The overall quality of the included studies for the meta-analysis was intermediate (figure 2). Not all studies were randomised clinical trials (RCTs) and not all RCTs were blinded; most of them were lacking blinding information. Also, most studies did not take seasonal changes into account. The number of participants varied, ranging between 28 and 172 .

All studies reported having only included patients with excellent adherence. Not all studies described how adherence was controlled.

\section{Primary outcome: exacerbation frequency after bacterial lysate add-on therapy Wheezing episodes}

Five studies reported a significant decrease in wheezing episodes in infants after bacterial lysate use (table 1) [31-33, 36, 37]. Four studies reported secondary prevention after experiencing wheezing episodes [31, 32, 36, 37]. Primary prevention of wheezing in very young infants (aged 3-9 months) with a risk for atopy was shown in a recent study [33]. Table 1 provides extensive data about the outcomes of those studies.

Sensitivity analysis, based on the outcome definition of wheezing and reported results, revealed only two studies were eligible for a meta-analysis [36, 37]. Pooled analysis resulted in an mean difference of -2.35 wheezing episodes (95\% CI $-3.03--1.67, \mathrm{p}<0.001)$ with low heterogeneity $\left(\mathrm{I}^{2}=0 \%, \mathrm{p}=0.65\right)$ (figure $\left.3 \mathrm{a}\right)$. The standardised mean difference was -0.96 (95\% CI $-1.26--0.66), \mathrm{p}<0.001$.

\section{Asthma exacerbations}

Five studies reported a decrease in exacerbation frequency after bacterial lysate use in asthma [29, 30, 35, 38, 39]. Mainly school children and adolescents were studied, and only one project studied adults with asthma. All studies reported a significant decrease in asthma exacerbations during the study period (table 1).

Sensitivity analysis, based on outcome definition of asthma exacerbations, age of participants and reported results, revealed three studies were eligible for a meta-analysis [29, 35, 38]. The pooled analysis showed an mean difference of -0.90 exacerbations in the same time period in favour of bacterial lysate 


\begin{tabular}{|c|c|c|c|c|c|c|c|c|c|}
\hline $\begin{array}{l}\text { First } \\
\text { author } \\
\text { [ref]. }\end{array}$ & Study design & $\begin{array}{l}\text { Subjects } \\
\text { (BL/ } \\
\text { control) n }\end{array}$ & Age & Intervention & $\begin{array}{c}\text { Concomitant treatment } \\
\text { BL/control } \mu \mathrm{g}\end{array}$ & $\begin{array}{l}\text { Study } \\
\text { regimen }\end{array}$ & $\begin{array}{c}\text { Outcome wheezing or } \\
\text { asthma episodes in } 1 \text { year } \\
\text { BL/control }\end{array}$ & p-value & $\begin{array}{l}\text { Outcome } \\
\text { immunology BL } \\
\text { compared to } \\
\text { controls }\end{array}$ \\
\hline \multicolumn{10}{|c|}{ Infant wheezing } \\
\hline $\begin{array}{c}\text { CHEN } \\
{[31]}\end{array}$ & $\begin{array}{c}\text { Open label, } \\
\text { prospective study }\end{array}$ & $43(24 / 19)$ & $\begin{array}{l}\text { 6-16 } \\
\text { months }\end{array}$ & $\begin{array}{l}\mathrm{OM}-85 \\
\text { versus } \\
\mathrm{SC}\end{array}$ & $\begin{array}{c}\text { Substitute treatment } \\
\text { Standard care consisted of } \\
\text { budesonide } 200 \mu \mathrm{g} \text { for } \\
3 \text { months }\end{array}$ & $\begin{array}{c}3 \text { months } \\
\text { OM-85/SC } \\
9 \text { months FU }\end{array}$ & $\begin{array}{l}25 \% \text { OM- } 85 \text { group } \\
\text { experienced }>3 \text { wheezing } \\
\text { episodes during follow-up; } \\
63.2 \% \mathrm{SC} \text { group } \\
\text { experienced }>3 \text { wheezing } \\
\text { episodes during follow-up }\end{array}$ & $<0.05$ & \\
\hline RazI [36] & Double-blind RCT & $75(35 / 40)$ & $1-6$ years & $\begin{array}{l}\text { OM-85 } \\
\text { versus } \\
\text { placebo }\end{array}$ & $\begin{array}{l}\text { Add-on treatment } \\
\text { Standard care with ICS } \\
200-800 \mu \mathrm{g} \cdot \text { day }^{-1} \\
\text { Not further specified }\end{array}$ & $\begin{array}{c}3 \text { months } \\
\text { OM-85/ } \\
\text { placebo } \\
9 \text { months FU }\end{array}$ & $3.6 \pm 1.6 / 5.8 \pm 2.7$ & $<0.01$ & \\
\hline $\mathrm{H}_{\text {AN }}[32]$ & Open label RCT & $136(74 / 62)$ & $\begin{array}{l}7 \text { months } \\
\text { to } 5 \text { years }\end{array}$ & $\begin{array}{l}\mathrm{OM}-85 \\
\text { versus } \\
\mathrm{SC}\end{array}$ & $\begin{array}{l}\text { Add-on treatment } \\
\text { Standard care: } \\
\text { glucocorticoid atomising } \\
\text { inhalation, aminophylline } \\
\text { and antibiotics }\end{array}$ & $\begin{array}{c}3 \text { months } \\
\text { OM-85/SC } \\
9 \text { months FU }\end{array}$ & $2.9 \pm 0.3 / 4.5 \pm 0.7$ & $<0.01$ & $\begin{array}{l}\text { Decrease serum } \\
\text { IL-17 } \\
\text { Increase serum } \\
\text { IFN- } \gamma\end{array}$ \\
\hline SLY [33] & Double-blind RCT & $59(29 / 30)$ & 3-9 months & $\begin{array}{l}\text { OM-85 } \\
\text { versus } \\
\text { placebo }\end{array}$ & $\begin{array}{c}\text { No mention of standard } \\
\text { care }\end{array}$ & $\begin{array}{c}6 \text { months } \\
\text { OM-85/ } \\
\text { placebo } \\
6 \text { months SC }\end{array}$ & $\begin{array}{l}9 \text { episodes }(0(0.0-0.0)) \\
17 \text { episodes }(0(0.0-1.0))\end{array}$ & 0.04 & \\
\hline $\begin{array}{c}\text { ConeJero } \\
\text { [37] }\end{array}$ & Double-blind RCT & $120(62 / 58)$ & $\begin{array}{l}\text { 6-35 } \\
\text { months }\end{array}$ & $\begin{array}{l}\text { MV130 } \\
\text { versus } \\
\text { placebo }\end{array}$ & $\begin{array}{l}\text { Add-on treatment } \\
\text { Standard care according } \\
\text { to GINA guidelines }\end{array}$ & $\begin{array}{l}6 \text { months } \\
\text { MV130/ } \\
\text { placebo } \\
6 \text { months FU }\end{array}$ & $2.8 \pm 1.8 / 5.3 \pm 3.2$ & $<0.01$ & \\
\hline \multicolumn{10}{|l|}{ Asthma } \\
\hline $\begin{array}{c}\text { CHEN } \\
{[38]}\end{array}$ & $\begin{array}{l}\text { Open label, } \\
\text { prospective study }\end{array}$ & $45(29 / 16)$ & $5-14$ years & $\begin{array}{l}\text { OM-85 } \\
\text { versus } \\
\text { SC }\end{array}$ & $\begin{array}{l}\text { Add-on treatment. } \\
\text { Standard care with ICS } \\
\text { Doses ICS not specified }\end{array}$ & $\begin{array}{c}3 \text { months } \\
\text { OM-85/SC } \\
9 \text { months FU }\end{array}$ & $1.0 \pm 0.9 / 2.2 \pm 1.5$ & $<0.05$ & $\begin{array}{c}\text { No decrease } \\
\text { serum IL-4 of } \lg E\end{array}$ \\
\hline LIAO [34] & Double-blind RCT & 62 & $\begin{array}{l}4.5 \text { years } \\
\text { (mean) }\end{array}$ & $\begin{array}{l}\text { OM-85 } \\
\text { versus } \\
\text { placebo }\end{array}$ & $\begin{array}{l}\text { Add-on treatment. } \\
\text { Standard care with ICS } \\
\text { Doses ICS not specified }\end{array}$ & $\begin{array}{c}3 \text { months } \\
\text { OM-85/ } \\
\text { placebo } \\
3 \text { months SC } \\
3 \text { months } \\
\text { OM-85/ } \\
\text { placebo } \\
3 \text { months FU }\end{array}$ & $\begin{array}{c}\text { Decreased number of } \\
\text { lower RTIs in asthma } \\
\text { patients, exacerbations not } \\
\text { described }\end{array}$ & & $\begin{array}{c}\text { Increase serum } \lg G \\
\text { and serum } \lg A\end{array}$ \\
\hline Lu [35] & Open label RCT & $60(24 / 36)$ & $5-15$ years & $\begin{array}{l}\mathrm{OM}-85 \\
\text { versus } \\
\mathrm{SC}\end{array}$ & $\begin{array}{l}\text { Add-on treatment. } \\
\text { Standard care with ICS } \\
\text { Doses ICS not specified }\end{array}$ & $\begin{array}{c}3 \text { months } \\
\text { OM-85/SC } \\
3 \text { months SC } \\
3 \text { months } \\
\text { OM-85/SC } \\
3 \text { months FU }\end{array}$ & $0.9 \pm 0.7 / 1.8 \pm 1.2$ & 0.01 & $\begin{array}{l}\text { Increase serum } \\
\text { IFN- } \gamma / \text { IL-4 ratio }\end{array}$ \\
\hline
\end{tabular}




\begin{tabular}{|c|c|c|c|c|c|c|c|c|c|}
\hline $\begin{array}{l}\text { First } \\
\text { author } \\
\text { [ref]. }\end{array}$ & Study design & $\begin{array}{l}\text { Subjects } \\
\text { (BL/ } \\
\text { control) } n\end{array}$ & Age & Intervention & $\begin{array}{c}\text { Concomitant treatment } \\
\mathrm{BL} / \text { control } \mu \mathrm{g}\end{array}$ & $\begin{array}{l}\text { Study } \\
\text { regimen }\end{array}$ & $\begin{array}{c}\text { Outcome wheezing or } \\
\text { asthma episodes in } 1 \text { year } \\
\text { BL/control }\end{array}$ & p-value & $\begin{array}{l}\text { Outcome } \\
\text { immunology BL } \\
\text { compared to } \\
\text { controls }\end{array}$ \\
\hline $\begin{array}{l}\text { KoATz } \\
{[30]}\end{array}$ & $\begin{array}{c}\text { Open label, } \\
\text { prospective } \\
\text { before/after study }\end{array}$ & 28 & $\begin{array}{l}16-65 \\
\text { years }\end{array}$ & $\begin{array}{l}\text { OM-85 } \\
\text { versus } \\
\text { SC }\end{array}$ & $\begin{array}{l}\text { Add-on treatment. } \\
\text { Standard care with ICS } \\
\text { Doses ICS not specified }\end{array}$ & $\begin{array}{l}9 \text { months SC } \\
3 \text { months } \\
\text { OM-85 } \\
12 \text { months FU }\end{array}$ & $0.1 \pm 0.7 / 2.1 \pm 1.2$ & 0.01 & $\begin{array}{c}\text { Increase serum } \\
\text { and secretory IgA } \\
\text { levels }\end{array}$ \\
\hline $\begin{array}{r}\text { EMERYK } \\
\text { [29] }\end{array}$ & Double-blind RCT & $150(74 / 76)$ & $6-16$ years & $\begin{array}{l}\text { Ismigen } \\
\text { versus } \\
\text { placebo }\end{array}$ & $\begin{array}{l}\text { Add-on treatment } \\
\text { Mean daily ICS dose: } \\
283 \pm 107 / 289 \pm 118\end{array}$ & $\begin{array}{l}3 \text { months } \\
\text { Ismigen/ } \\
\text { placebo } \\
9 \text { months FU }\end{array}$ & $1.1 \pm 1.3 / 1.9 \pm 2.0$ & 0.01 & \\
\hline
\end{tabular}

Data are presented as mean \pm SD or median (interquartile range), unless otherwise stated. BL: bacterial lysate; SC: standard care; ICS: inhaled corticosteroids; FU: follow-up; RCT: randomised controlled trial; OM-85: Broncho-Vaxom; ICS: inhaled corticosteroid; IL: interleukin; IFN: interferon; Ig: immunoglobulin; RTI: respiratory tract infection; GINA: Global Initiative for Asthma. 
FIGURE 2 Bias included randomised controlled trials for meta-analysis.

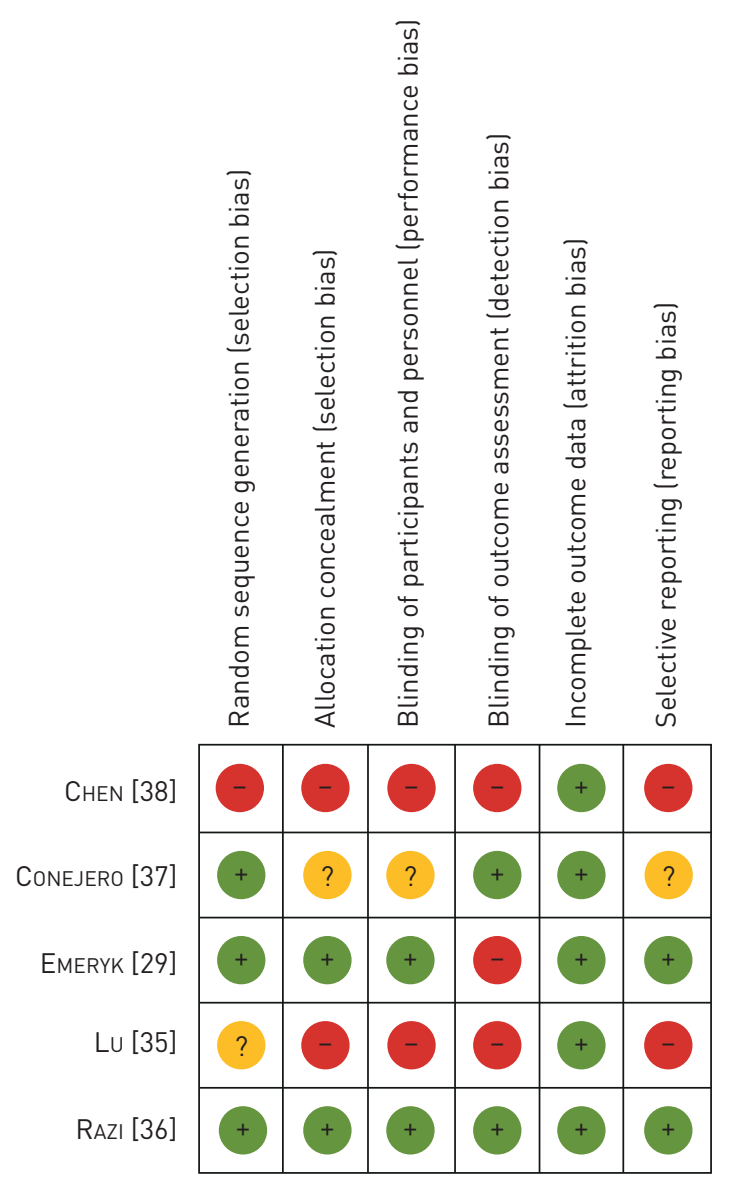

(95\% CI $-1.23--0.57, \mathrm{p}<0.001)$ with low heterogeneity $\left(\mathrm{I}^{2}=0 \%, \mathrm{p}=0.78\right)$ and an standardised mean difference of -0.68 (95\% CI $-0.99--0.36, \mathrm{p} \leqslant 0.001)$ (figure $3 \mathrm{a}$ ).

\section{PCBL versus $P M B L$}

In regard to the possible differences between PCBL and PMBL, pooled analysis for both PCBL and PMBL studies was performed. There was a benefit for the use of PCBL in the prevention of asthma exacerbations and wheezing episodes with an mean difference of -1.31 episodes $(95 \% \mathrm{CI}-2.00--0.62, \mathrm{p}<0.001)$ with high heterogeneity. Pooled analysis for PMBL showed comparable but non-significant results with a mean difference of -1.60 episodes (95\% CI $-3.27-0.06, \mathrm{p}=0.06$ ) (figure $3 \mathrm{~b}$ ).

\section{Secondary end-points}

Time to first wheezing episode/exacerbation

Time to first wheezing episode increases with bacterial lysate administration $[33,37]$. ConEJERo et al. [37] described an increase in time to first wheezing episode, a mean number of 41 days versus 5 days with MV130 use compared to placebo (HR 0.45, 95\% CI 0.30- 0.67, p<0.005). SLY et al. [33] described an increase in time to first wheezing episode in very young infants in favour of OM-85 (median (IQR) 442.0 (853.0-124.0) days versus 85.0 (386.0-54.0) days, $\mathrm{p}=0.006)$ for the placebo group.

No increase in time to first asthma exacerbation was observed. However, EMERYK et al. [29] described an increase in time to second and third exacerbation by 55\% (HR 0.45, 95\% CI $0.25-0.77, \mathrm{p}=0.002$ ) and by $74 \%$ (HR $0.26,95 \%$ CI $0.12-0.58, \mathrm{p}<0.001$ ) with the administration of Ismigen.

Disease control

Conejero et al. [37] reported fewer overall symptoms of childhood wheezing during wheezing attacks and during the complete study ( $\mathrm{p}<0.005$ for both). EMERYK et al. [29] reported no significant improvement in asthma control test scores after 4, 6 and 9 months (mean 5.4 versus 5.6, $\mathrm{p}=0.69$ ). 


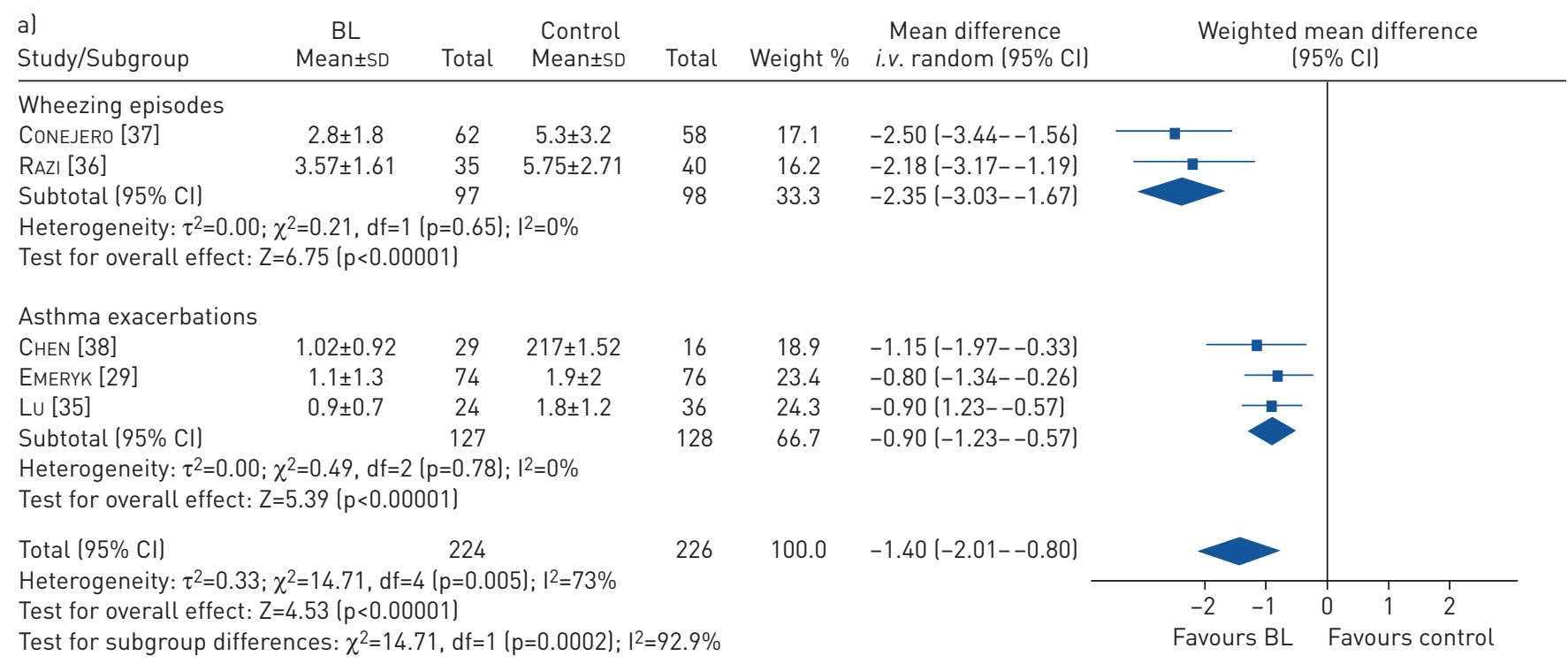

\begin{tabular}{|c|c|c|c|c|c|c|c|c|}
\hline $\begin{array}{l}\text { b) } \\
\text { Study/Subgroup }\end{array}$ & $\begin{array}{c}\mathrm{BL} \\
\text { Mean } \pm \mathrm{SD}\end{array}$ & Total & $\begin{array}{l}\text { Control } \\
\text { Mean } \pm \text { SD }\end{array}$ & Total & Weight $\%$ & $\begin{array}{l}\text { Mean difference } \\
\text { i.v. random }(95 \% \mathrm{Cl})\end{array}$ & $\begin{array}{r}\text { Weighted } \mathrm{m} \\
195\end{array}$ & $\begin{array}{l}\text { ean difference } \\
5 \% \mathrm{CI}\end{array}$ \\
\hline \multicolumn{9}{|l|}{ PCBL } \\
\hline CHEN [38] & $1.02 \pm 0.92$ & 29 & $2.17 \pm 1.52$ & 16 & 18.9 & $-1.15(-1.97--0.33)$ & $\rightarrow$ & \\
\hline RAZI [36] & $3.57 \pm 1.61$ & 35 & $5.75 \pm 2.71$ & 40 & 16.2 & $-2.18(-3.17--1.19)$ & & \\
\hline Subtotal $(95 \% \mathrm{CI})$ & & 88 & & 92 & 59.5 & $-1.31(-2.00--0.62)$ & & \\
\hline \multicolumn{9}{|c|}{ Heterogeneity: $\tau^{2}=0.23 ; \chi^{2}=5.15, d f=2(p=0.08) ;\left.\right|^{2}=61 \%$} \\
\hline \multicolumn{9}{|l|}{ PMBL } \\
\hline CONEJERO [37] & $2.8 \pm 1.8$ & 62 & $5.3 \pm 3.2$ & 58 & 17.1 & $-2.50(-3.44--1.56)$ & & \\
\hline EMERYK [29] & $1.1 \pm 1.3$ & 74 & $1.9 \pm 2$ & 76 & 23.4 & $-0.80(-1.34--0.26)$ & 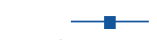 & \\
\hline Subtotal $(95 \% \mathrm{Cl})$ & & 136 & & 134 & 40.5 & $-1.60(3.27--0.06)$ & & \\
\hline \multicolumn{9}{|c|}{$\begin{array}{l}\text { Heterogeneity: } \tau^{2}=1.29 ; \chi^{2}=9.50, d f=1(p=0.002) ; I^{2}=89 \% \\
\text { Test for overall effect: } Z=1.89(p=0.06)\end{array}$} \\
\hline
\end{tabular}

FIGURE 3 a) Meta-analysis of wheezing episodes and asthma exacerbations. b) Meta-analysis of polyvalent chemical bacterial lysate (PCBL) and polyvalent mechanical bacterial lysate (PMBL). BL: bacterial lysate.

Wheezing days in preschool children

Studies reporting symptom duration all reported a decrease in wheezing days in favour of bacterial lysate use. RAZI et al. [36] showed a mean difference of -22.42 wheezing days $(\mathrm{p}<0.001)$ per patient in favour of bacterial lysate use in the observation period of 12 months. In addition, HAN et al. [32] reported a difference of 5.7 "asthma" days $(10.2 \pm 1.4$ versus $4.5 \pm 0.9(\mathrm{p}=0.32))$ in favour of bacterial lysate use. Similarly, Conejero et al. [37] found a decrease in wheezing days of 6.0 versus 7.9 in favour of bacterial lysate use.

Use of antibiotics

Antibiotic consumption for asthma exacerbations was decreased by 3.8 days in school children in one study $(\mathrm{p}<0.01)[35]$.

Adverse events

In all studies combined, adverse events were reported 172 times; 85 times for bacterial lysates, and 87 times for placebo or standard care. Common cold and abdominal discomfort were reported most often $[29,30,32,33,35-37]$. 
Immunological effects of bacterial lysates

Immunological studies with bacterial lysates in asthma were all performed with OM-85, except for one which used MV130. Six studies reported immunological findings of in vivo bacterial lysate administration in animals $[22,23,40-43]$. OM-85 was administered via drinking water or gavage in asthmatic mouse or rat models which were sensitised with either intranasal or intraperitoneal injection of ovalbumin. OM-85 administration resulted in a decrease of lymphocytes, eosinophils, macrophages and eotaxin, IL-4, IL-5 and IL-13 and an increase of IFN- $\gamma$ in bronchoalveolar lavage fluid of these animals [22, 23, 40-43]. Interestingly, the level of the regulatory cytokine IL-10 was reported to decrease or to increase upon in vivo bacterial lysate administration [22, 43]. An upregulation of CD86 on resident airway dendritic cells and an increase of FoxP3 ${ }^{\text {pos }}$ regulatory T-cells (Treg) was measured in airway and blood samples [22, 23]. Conversion of FoxP3 ${ }^{\text {neg }}$ into FoxP3 $3^{\text {pos }}$ Tregs was shown to be driven by $\mathrm{CD} 103^{\text {pos }}$ dendritic cells. Furthermore, the frequency of IL-10-secreting cells in the trachea increased following OM-85 treatment, and $\mathrm{CD} 4^{\text {pos }} \mathrm{T}$-cells from the trachea of bacterial lysate-treated mice conferred protection against airway inflammation in adoptive transfer experiments [22]. This protection was most likely mediated by a subset

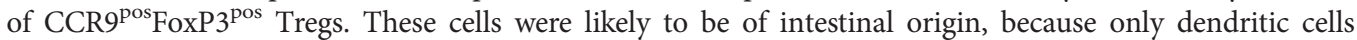
from mesenteric lymph nodes or Peyer's patches are thought to have the capacity to imprint CCR9 on lymphocytes. Taken together, these findings would be consistent with a model in which bacterial lysate promotes the development of $\mathrm{CCR}^{{ }^{\text {pos }}} \mathrm{FoxP}^{\mathrm{pos}}$ Tregs in mesenteric lymph nodes and that these cells subsequently migrate into the airways and provide protection [22]. These critical immunological changes are held responsible for an observed less severe airway hyperresponsiveness in animal models and improved protection against airway inflammation in OM-85-treated animals [22, 23, 42]. Also, a reduction of airway wall thickness and luminal stenosis in mice has been described after OM-85 administration [42].

Nine studies reported immunological findings in studies with human material: seven in vivo and two in vitro studies [14, 30, 35, 44-47].

In vitro studies show induction of IL- 6 , IL- 8 and tumour necrosis factor (TNF)- $\alpha$ in OM-85-stimulated human lung fibroblasts. Moreover, human rhinovirus replication in bronchial epithelial cells was lowered after stimulation with OM-85 [44, 45].

Igs in humans might change after OM-85 administration; an increase in serum and secretory IgA and serum IgG and a decrease in serum IgE have been described in patients with asthma $[30,34,38,46]$. Also, changes in serum cytokine and chemokine levels have been observed, with a decline in serum IL-4, and an increase in IL-10, IL-17 and IFN- $\gamma[32,35,38,42]$. These results are in accordance with the PMBL MV130 study, where an increase in serum TNF- $\alpha$, IL-1 $\beta$, IL-6, IL-10, IL-17A, IL-23 and IFN- $\gamma$ was seen in the serum of healthy persons and patients with recurrent RTIs [14]. All effects as presented above are summarised in figure 4.

\section{Discussion}

Disease exacerbations are the major cause of morbidity in preschool wheezing and asthma. Prevention of exacerbations is therefore highly urgent. In this meta-analysis, we provide evidence that bacterial lysates can be effective in exacerbation prevention in preschool wheezing and asthma; the effect observed was more prominent in preschool wheezing. Moreover, positive effects are observed on wheezing days in children, days of antibiotic use for asthma exacerbations, and time between first and second exacerbations.

In this systematic review, we included studies performed with all existing and commercially available bacterial lysate preparations. This remains at odds with a recent meta-analysis by YIN et al. [20] who investigated the effects of only one preparation (OM-85) and included a variety of non-English published studies. However, in line with our meta-analysis, YIN et al. [20] report a positive effect of OM-85, in terms of a decrease in total number of wheezing days.

Whereas bacterial strains present in these bacterial lysates are similar, administration and production differ: OM-85 is a capsule taken orally with some fluid, Ismigen is a sublingual tablet and MV130 is a sublingual spray. More importantly, Ismigen and MV130 are both PMBL with non-denaturated proteins and might, therefore, induce a different immune response than OM-85 as it is a PCBL. As almost all laboratory studies investigated the effect of OM-85 and only one study showed immunological data of the PMBL MV130, it is conceivable that the described working mechanisms are only valid for OM-85. More studies should be performed to identify this and possible additional immunomodulatory pathways in humans.

The immune-modulating effect of bacterial lysates touches both humoral and cellular immunity. Based on several in vitro studies, animal models and studies in diverse human diseases, the clinical effect of bacterial lysates is based on four cellular mechanisms. Firstly, after bacterial lysate stimulation, dendritic cells in the Peyer's patches of the gut-associated lymphoid tissue (GALT) trigger activation of antigen-specific 

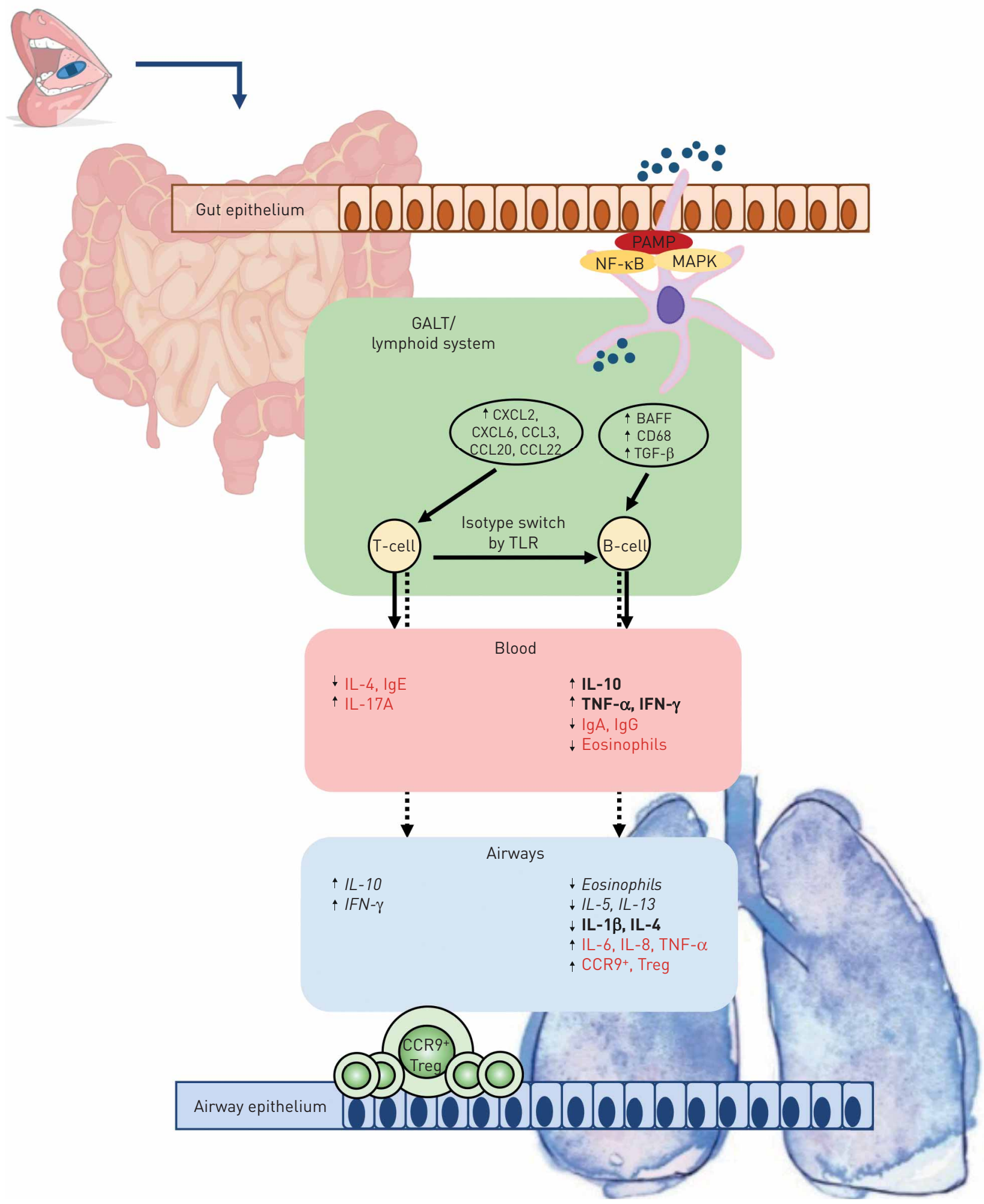

FIGURE 4 Immunological effects of Broncho-Vaxom (OM-85) in animals and humans. Red text: human only; italic text: animal only; bold text:

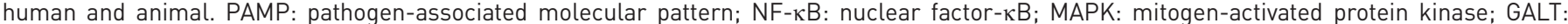
gut-associated lymphoid tissue; TGF: transforming growth factor; TLR: Toll-like receptor; IL: interleukin; Ig: immunoglobulin; TNF: tumour necrosis factor; Treg: regulatory T-cell.

T-lymphocytes that modulate B-cell isotype switching into Ig-secreting cells. This effect is mediated by the synthesis of cytokines and growth factors $[13,18]$. Activated dendritic cells, T-lymphocytes and B-lymphocytes continue to mature and proliferate in the mesenteric lymph nodes. Secondly, 
GALT-generated cells, including Treg cells, migrate into the thoracic duct and are disseminated by the systemic circulation to extra-intestinal sites, including the upper and lower respiratory tract [22, 23]. This results in polyclonal activation of the immune system, which involves both the innate and adaptive immune responses with induction of IFN- $\alpha$ and IFN- $\beta$ and the control of an excessive inflammatory reaction through the generation of Tregs $[13,22]$. Thirdly, a wide array of immune responses is shown in animal studies after bacterial lysate application involving polyclonal production of immunoglobulins, resulting in a decreased susceptibility to various respiratory pathogens [19]. Fourth, an excessive inflammatory response and attenuation of Th2-driven allergic predisposition might lead to correction of the Th1/Th2 lymphocyte imbalance, where it seems plausible that bacterial lysates induce increased activation of Th1 cells, possibly resulting in Th2 suppression [18]. It must be stated that the study of pathophysiology in animal models differs from that in humans. Whereas all animal model studies looked at local respiratory tract responses, in humans generally the blood was investigated. Also, species-specific differences might influence outcomes.

Another hypothesis suggests that bacterial lysates may reinforce post-natal maturation of Treg and Th1 lymphocyte functions. This process is thought to be physiologically driven by the gastrointestinal commensal microflora [48]. The effect of bacterial lysates on the human microbiome is not sufficiently explored. However, the currently ongoing Orbex study (NCT02148796) and the Breathe study (NL5752) will address these intriguing questions.

In this context it is worth mentioning that studies have suggested that preparations aiming at modification of the gut microbiome, including prebiotics and probiotics, can prevent asthma or reduce the severity of asthma [49]. However, results of recently published systematic reviews and meta-analysis were rather disappointing. Administration of probiotics early in life have not been proven to reduce the risk of developing asthma or preschool wheezing $[50,51]$. Therefore, according to available evidence, there are no data supporting the use of probiotics for add-on treatment in preschool wheezing or asthma.

To sum up, based on the above-mentioned hypothesised working mechanism (figure 4), bacterial lysates can be considered as an effective add-on therapy in preschool wheezing and asthma, especially when a patient suffers from recurrent RTI.

This systematic review and meta-analysis has several limitations. Our thorough search strategy identified 2016 articles. Strict inclusion criteria dictated that only 22 articles were suitable for this review, of which only five were included in the meta-analysis. Even though the search strategy was very comprehensive, some studies may not have been identified, especially if they had never been published or were published in less frequently indexed languages. Another limitation is that many of the studies included in this systematic review are of moderate quality, which may make our review prone to systematic bias. To determine a reliable study outcome, all published articles were considered for meta-analysis in this study.

In the studies included in this meta-analysis, most asthma studies were performed in school children with asthma, usually those with atopic asthma. Currently, there are no data available on the effect of bacterial lysates in adults with asthma, except for a single report, in which the effects of bacterial lysates in COPD, asthma and allergic rhinitis patients with recurrent RTIs solely are described [30]. No large RCT in adult asthma has been performed to date. More specifically, the effects of bacterial lysates in nonallergic asthma have not been described, neither in adults nor in children.

Another question arises from the analysis of the treatment length with bacterial lysate in our meta-analysis. The length of intervention in all included studies was 3 months for OM-85 and 6 months for MV-130. Not all studies specified the exact time of year of the intervention commencement. EMERYK et al. [29] and SLY et al. [33] considered the seasonal nature of exacerbation frequency and scheduled the administration of bacterial lysates before the viral season. A trial evaluating the effect of administering bacterial lysates for 12 consecutive months should provide new information on these points.

The optimal therapy regimen for bacterial lysates, length of therapy and target population still need to be established. Two clinical trials are expected to address these points in terms of clinical outcomes such as wheezing or exacerbation episodes and lung function, immunological parameters and change in the microbiome. Results from the Breathe study (NL5752), which includes adults with severe asthma, are expected in late 2020, and those for the Orbex study (NCT02148796), which includes children between 5 and 16 months old that are at risk for asthma development, are expected in 2024.

Asthma management mainly consists of therapeutic intervention with long-acting $\beta 2$-agonists and inhaled corticosteroids (ICS) according to the Global Initiative for Asthma (GINA) guidelines [52]. ICS dosages are increased until adequate asthma control is achieved. Most asthma patients reach adequate control with low to intermediate doses of ICS. High doses of ICS are prescribed in $24 \%$ of asthma patients [9]. Rather than increasing ICS dose or using add-on biologicals, patients with partially or uncontrolled asthma that 
experience frequent RTIs could benefit from add-on bacterial lysate treatment. Bacterial lysates are well tolerated and available for a reasonable price in several European and Asian countries. Considering the adverse effects of maintenance oral corticosteroids or oral antibiotics, bacterial lysates are expected to be safer and more cost-effective, even if their clinical efficacy is moderate $[52,53]$.

This review shows that bacterial lysates are a promising add-on treatment to current management of preschool wheezing and childhood asthma. There is a tremendous need for placebo-controlled RCTs in adults with different asthma phenotypes to determine if there is a true place for bacterial lysates as add-on therapy in adults with asthma.

However, based on this meta-analysis and systematic review, bacterial lysates could be considered as a safe and effective add-on therapy in preschool wheezing and children with recurrent asthma exacerbations.

Acknowledgements: We thank K. de Jong and N. van Houten (Medical Library of the Franciscus Gasthuis \& Vlietland, Rotterdam, The Netherlands) and A. Ajdukiewicz-Tarkowska (Library of the Medical University of Warsaw, Warsaw, Poland) for their help with preparing the database search.

Author contributions: G.A. Tramper-Stranders and W. Feleszko conceived the initial idea for this review. G.M. de Boer, J. Żółkiewicz and K. Strzelec performed the search and selected the studies for this review and meta-analysis. G.M. de Boer and J. Żółkiewicz conducted the meta-analysis under supervision of M. Ruszczyński. G.M. de Boer, G.A. Tramper-Stranders and G.J. Braunstahl constructed table 1. G.M. de Boer, G.A. Tramper-Stranders and R.W. Hendriks reviewed the immunology data and constructed figure 4. G.M. de Boer, W. Feleszko and G.A. Tramper-Stranders wrote the manuscript and all authors reviewed it during different phases. All authors approved the final version of the manuscript.

Conflict of interest: G.M. de Boer has nothing to disclose. J. Żółkiewicz has nothing to disclose. K. Strzelec has nothing to disclose. M. Ruszczyński has nothing to disclose. R.W. Hendriks has nothing to disclose. G.J. Braunstahl has nothing to disclose. W. Feleszko reports speaker honoraria from Vifor Pharma. G.A. Tramper-Stranders reports grants from European Society for Pediatric Infectious Diseases, Stichting Coolsingel, and a grant, personal fees and non-financial support from OM-Pharma for an affiliated project during the conduct of the study. All fees were paid to the research foundation.

\section{References}

1 Selroos O, Kupczyk M, Kuna P, et al. National and regional asthma programmes in Europe. Eur Respir Rev 2015; 24: 474-483

Papi A, Brightling C, Pedersen SE, et al. Asthma. Lancet 2018; 391: 783-800.

Rabe KF, Watz H. Chronic obstructive pulmonary disease. Lancet 2017; 389: 1931-1940.

Jartti T, Gern JE. Role of viral infections in the development and exacerbation of asthma in children. J Allergy Clin Immunol 2017; 140: 895-906.

5 Bacharier LB, Guilbert TW. Diagnosis and management of early asthma in preschool-aged children. J Allergy Clin Immunol 2012; 130: 287-296.

6 Brand PL, Caudri D, Eber E, et al. Classification and pharmacological treatment of preschool wheezing: changes since 2008. Eur Respir J 2014; 43: 1172-1177.

7 Adamiec A, Ambrozej D, Ryczaj K, et al. Preschool wheezing diagnosis and management: survey of physicians' and caregivers' perspective. Pediatr Allergy Immunol 2020; 31: 206-209.

8 Edwards MR, Walton RP, Jackson DJ, et al. The potential of anti-infectives and immunomodulators as therapies for asthma and asthma exacerbations. Allergy 2018; 73: 50-63.

9 Hekking PP, Wener RR, Amelink M, et al. The prevalence of severe refractory asthma. J Allergy Clin Immunol 2015; 135: 896-902.

10 Jackson DJ, Hartert TV, Martinez FD, et al. Asthma: NHLBI workshop on the primary prevention of chronic lung diseases. Ann Am Thorac Soc 2014; 11: Suppl. 3, S139-S145.

11 van der Meer V, van Stel HF, Bakker MJ, et al. Weekly self-monitoring and treatment adjustment benefit patients with partly controlled and uncontrolled asthma: an analysis of the SMASHING study. Respir Res 2010; 11: 74.

12 Le Souef P. Viral infections in wheezing disorders. Eur Respir Rev 2018; 27: 170133.

13 Esposito S, Soto-Martinez ME, Feleszko W, et al. Nonspecific immunomodulators for recurrent respiratory tract infections, wheezing and asthma in children: a systematic review of mechanistic and clinical evidence. Curr Opin Allergy Clin Immunol 2018; 18: 198-209.

14 Cirauqui C, Benito-Villalvilla C, Sanchez-Ramon S, et al. Human dendritic cells activated with MV130 induce Th1, Th17 and IL-10 responses via RIPK2 and MyD88 signalling pathways. Eur J Immunol 2018; 48: 180-193.

15 Cazzola M, Rogliani P, Curradi G. Bacterial extracts for the prevention of acute exacerbations in chronic obstructive pulmonary disease: a point of view. Respir Med 2008; 102: 321-327.

16 Del-Rio-Navarro BE, Espinosa Rosales F, Flenady V, et al. Immunostimulants for preventing respiratory tract infection in children. Cochrane Database Syst Rev 2006;4 : CD004974.

17 Chyrek-Borowska S, Moniuszko T, Szymanski W, et al. Broncho-vaxom in the treatment and prophylaxis of recurrent respiratory tract infections in bronchial asthma. Pneumonol Alergol Pol 1992; 60: Suppl. 2, 117-119.

18 Kearney SC, Dziekiewicz M, Feleszko W. Immunoregulatory and immunostimulatory responses of bacterial lysates in respiratory infections and asthma. Ann Allergy Asthma Immunol 2015; 114: 364-369.

19 Pasquali C, Salami O, Taneja M, et al. Enhanced mucosal antibody production and protection against respiratory infections following an orally administered bacterial extract. Front Med (Lausanne) 2014; 1: 41.

20 Yin J, Xu B, Zeng X, et al. Broncho-Vaxom in pediatric recurrent respiratory tract infections: a systematic review and meta-analysis. Int Immunopharmacol 2018; 54: 198-209. 
21 Parola C, Salogni L, Vaira X, et al. Selective activation of human dendritic cells by OM-85 through a NF-kB and MAPK dependent pathway. PLoS One 2013; 8: e82867.

22 Navarro S, Cossalter G, Chiavaroli C, et al. The oral administration of bacterial extracts prevents asthma via the recruitment of regulatory T cells to the airways. Mucosal Immunol 2011; 4: 53-65.

23 Strickland DH, Judd S, Thomas JA, et al. Boosting airway T-regulatory cells by gastrointestinal stimulation as a strategy for asthma control. Mucosal Immunol 2011; 4: 43-52.

24 Liberati A, Altman DG, Tetzlaff J, et al. The PRISMA statement for reporting systematic reviews and meta-analyses of studies that evaluate health care interventions: explanation and elaboration. J Clin Epidemiol 2009; 62: e1-34.

25 Moher D, Liberati A, Tetzlaff J, et al. Preferred reporting items for systematic reviews and meta-analyses: the PRISMA statement. J Clin Epidemiol 2009; 62: 1006-1012.

26 Review Manager (RevMan). Version 5.3. Copenhagen, The Nordic Cochrane Centre, The Cochrane Collaboration. 2014.

27 Higgins J, Green S. Cochrane Handbook for Systematic Reviews of Interventions. Chichester, Wiley-Blackwell, 2011.

28 OM-Pharma. 2016. Summary of Product Characteristics. https://myhealthbox.eu/nl/view/1717481/1229962e24dc $324 \mathrm{~b} 4 \mathrm{c} 23 \mathrm{f} 24 \mathrm{db} 468 \mathrm{f} 6 \mathrm{ec} / \mathrm{leaflet}$.

29 Emeryk A, Bartkowiak-Emeryk M, Raus Z, et al. Mechanical bacterial lysate administration prevents exacerbation in allergic asthmatic children: The EOLIA study. Pediatr Allergy Immunol 2018; 29: 394-401.

30 Koatz AM, Coe NA, Ciceran A, et al. Clinical and immunological benefits of OM-85 bacterial lysate in patients with allergic rhinitis, asthma, and COPD and recurrent respiratory infections. Lung 2016; 194: 687-697.

31 Chen ZG, Ji JZ, Li M, et al. [Immunoregulants improves the prognosis of infants with wheezing]. Nan Fang Yi Ke Da Xue Xue Bao 2007; 27: 1612-1613.

32 Han RF, Li HY, Wang JW, et al. Study on clinical effect and immunologic mechanism of infants capillary bronchitis secondary bronchial asthma treated with bacterial lysates Broncho-Vaxom. Eur Rev Med Pharmacol Sci 2016; 20: 2151-2155.

33 Sly PD, Galbraith S, Islam Z, et al. Primary prevention of severe lower respiratory illnesses in at-risk infants using the immunomodulator OM-85. J Allergy Clin Immunol 2019; 144: 870-872.

34 Liao JY, Zhang T. [Influence of OM-85 BV on hBD-1 and immunoglobulin in children with asthma and recurrent respiratory tract infection]. Zhongguo Dang Dai Er Ke Za Zhi 2014; 16: 508-512.

$35 \mathrm{Lu} \mathrm{Y,} \mathrm{Li} \mathrm{Y,} \mathrm{Xu} \mathrm{L,} \mathrm{et} \mathrm{al.} \mathrm{Bacterial} \mathrm{lysate} \mathrm{increases} \mathrm{the} \mathrm{percentage} \mathrm{of} \mathrm{natural} \mathrm{killer} \mathrm{T} \mathrm{cells} \mathrm{in} \mathrm{peripheral} \mathrm{blood} \mathrm{and}$ alleviates asthma in children. Pharmacology 2015; 95: 139-144.

36 Razi CH, Harmanci K, Abaci A, et al. The immunostimulant OM-85 BV prevents wheezing attacks in preschool children. J Allergy Clin Immunol 2010; 126: 763-769.

37 Conejero L, Nieto A, Brandi P, et al. Bacterial immunotherapy in children with wheezing attacks: clinical impact and mechanism of action. Eur Respir J 2019; 54: Suppl. 63, PA4998.

38 Chen ZG, Ji JZ, Li M, et al. Effect and analysis of clinical efficacy of immunomodulator on serum levels of IL-4 and IFN-gamma in asthmatic children. J Sun Yat-sen Univ Med Sci 2009; 30: 3.

39 Liao JY, Zhang T. [Effects of montelukast sodium and bacterial lysates on airway remodeling and expression of transforming growth factor-betal and Smad7 in guinea pigs with bronchial asthma]. Zhongguo Dang Dai Er Ke Za Zhi 2018; 20: 1063-1069.

40 Rodrigues A, Gualdi LP, de Souza RG, et al. Bacterial extract (OM-85) with human-equivalent doses does not inhibit the development of asthma in a murine model. Allergol Immunopathol (Madr) 2016; 44: 504-511.

41 Nemeth A, Magyar P. Broncho-Vaxom inhibits histamine release from rat mast cells induced by compound 48/80 and ionophore A23187. Agents Actions 1989; 27: 43-45.

42 Liu C, Huang R, Yao R, et al. The immunotherapeutic role of bacterial lysates in a mouse model of asthma. Lung 2017; 195: 563-569.

43 Fu R, Li J, Zhong H, et al. Broncho-Vaxom attenuates allergic airway inflammation by restoring GSK3beta-related T regulatory cell insufficiency. PloS One 2014; 9: e92912.

44 Roth M, Pasquali C, Stolz D, et al. Broncho Vaxom (OM-85) modulates rhinovirus docking proteins on human airway epithelial cells via Erk1/2 mitogen activated protein kinase and cAMP. PloS One 2017; 12: e0188010.

45 Keul R, Roth M, Papakonstantinou E, et al. Induction of interleukin 6 and interleukin 8 expression by Broncho-Vaxom (OM-85 BV) via C-Fos/serum responsive element. Thorax 1996; 51: 150-154.

46 Weiss S, Fux T. [Effect of Broncho-Vaxom on serum IgE and IgG levels in patients with bronchial asthma and chronic obstructive lung disease. A placebo-controlled double-blind study]. Schweiz Med Wochenschr 1987; 117: 1514-1518.

47 Han L, Zheng CP, Sun YQ, et al. A bacterial extract of OM-85 Broncho-Vaxom prevents allergic rhinitis in mice. Am J Rhinol Allergy 2014; 28: 110-116.

48 Lau S. Bacterial lysates in food allergy prevention. Curr Opin Allergy Clin Immunol 2013; 13: $293-295$.

49 Feleszko W, Jaworska J, Rha RD, et al. Probiotic-induced suppression of allergic sensitization and airway inflammation is associated with an increase of T regulatory-dependent mechanisms in a murine model of asthma Clin Exp Allergy 2007; 37: 498-505.

50 Elazab N, Mendy A, Gasana J, et al. Probiotic administration in early life, atopy, and asthma: a meta-analysis of clinical trials. Pediatrics 2013; 132: e666-e676.

51 Azad MB, Coneys JG, Kozyrskyj AL, et al. Probiotic supplementation during pregnancy or infancy for the prevention of asthma and wheeze: systematic review and meta-analysis. BMJ 2013; 347: f6471.

52 Reddel HK, FitzGerald JM, Bateman ED, et al. GINA 2019: a fundamental change in asthma management: treatment of asthma with short-acting bronchodilators alone is no longer recommended for adults and adolescents. Eur Respir J 2019; 53: 1901046.

53 Lefebvre P, Duh MS, Lafeuille MH, et al. Acute and chronic systemic corticosteroid-related complications in patients with severe asthma. J Allergy Clin Immunol 2015; 136: 1488-1495. 